\title{
Erratum to: Absence: An Indo-Analytic Inquiry
}

\author{
Anand Jayprakash Vaidya ${ }^{1}$. \\ Purushottama Bilimoria ${ }^{2}$ • Jaysankar L. Shaw ${ }^{3}$
}

Published online: 24 August 2016

(C) Springer Science+Business Media Dordrecht 2016

\section{Erratum to: Sophia \\ DOI 10.1007/s11841-016-0547-8}

The original version of this article unfortunately contained a mistake: Jaysankar L. Shaw's name was incorrectly presented as Jayshankar. The original article was corrected.

The online version of the original article can be found at http://dx.doi.org/10.1007/s11841-016-0547-8.

$\triangle$ Anand Jayprakash Vaidya

anand.vaidya@sjsu.edu

$\triangle$ Purushottama Bilimoria

p.bilimoria@unimelb.edu.au

1 San Jose State University, San Jose, CA, USA

2 Graduate Theological Union and UC Berkeley, Berkeley, CA, USA

3 Victoria University of Wellington, Wellington, New Zealand 